\title{
Developing Guidance to Support Sustainable Spent Pot Lining (SPL) Management Across the Aluminum Industry
}

\author{
PERNELLE NUNEZ ${ }^{1,2}$ \\ 1.-International Aluminium Institute, 2 Duke Street St James's, London SW1Y 6BN, UK. \\ 2.-e-mail: nunez@world-aluminium.org
}

Managing waste responsibly and sustainably is a challenge facing many industries today. The aluminum industry is no different in grappling with stakeholder concerns around waste management, and the environmental, and social, impacts of different waste management strategies. This note provides a case study on how the aluminum industry, through the International Aluminium Institute (IAI), is taking steps towards improving the sector's environmental footprint through the sharing of knowledge, expertise, and good practice, and advocating for increased stakeholder collaboration to overcome challenges.

Spent pot lining (SPL) is a solid waste generated from primary aluminum production, and its management has posed a challenge for the aluminum industry for many years. SPL is classified as a hazardous waste or is subject to strict regulations in most jurisdictions due to its fluoride and cyanide content $^{1,2}$. It also has the potential for volatile reactions with water to produce explosive gases ${ }^{2,3}$. The classification of SPL as a hazardous waste means that it is subject to the protocols of the Basel Convention on the Transboundary Movement of Hazardous Wastes and Their Disposal, which can complicate its handling, transportation, and end-oflife practices ${ }^{4}$.

SPL is the second largest solid waste stream generated from the primary aluminum production process after bauxite residue ${ }^{5}$. The management of waste is under increasing scrutiny by stakeholders, and industries are looking for ways to manage waste more effectively. In 2018, the International Aluminium Institute (IAI) initiated an industrywide dialog on SPL management as part of its work program with the aim of improving the management of SPL across the industry by:

1. Understanding the current landscape of SPL management globally

(Received April 14, 2020; accepted July 22, 2020;

published online August 19, 2020)
2. Facilitating discussion, information sharing, and good practice exchange between industry stakeholders

3. Identifying specific ways in which the IAI could support stakeholders in making informed plans and decisions about future SPL activities

The IAI, a leading global industry association for aluminum producers, has focused increasingly in recent years on supporting the development of sustainable practices across the industry by bringing together industry stakeholders to collaborate on issues of common concern. The IAI regularly facilitates expert working groups, collects and publishes industry data, and develops guidelines and frameworks to support industry efforts on improving emissions management, waste management, and other broader environmental and sustainability issues $^{6,7}$.

\section{ESTABLISHING THE KNOWLEDGE BASE: SPL GENERATION AND MANAGEMENT PRACTICES}

Aluminum is smelted in steel cells that are lined with an insulating refractory lining and an interior carbon lining (Fig. 1). When this lining deteriorates and comes to the end of its life, it is removed from the cell and from this point on is referred to as "spent pot lining." The cell lining typically has a useful life of approximately 4 years to 7 years. The lining can be removed from the cell as mixed SPL with no differentiation between the two lining layers, or it can be separated into a first cut (carbon lining) and a second cut (refractory lining). Data collected annually by the IAI estimate that approximately $25 \mathrm{~kg}$ of SPL is generated per tonne of primary aluminum production for all types of cell technology 5 .

Aluminum is a widely used metal across a variety of applications including construction, transportation, packaging, and electrical and consumer goods. Demand for aluminum is expected to grow 


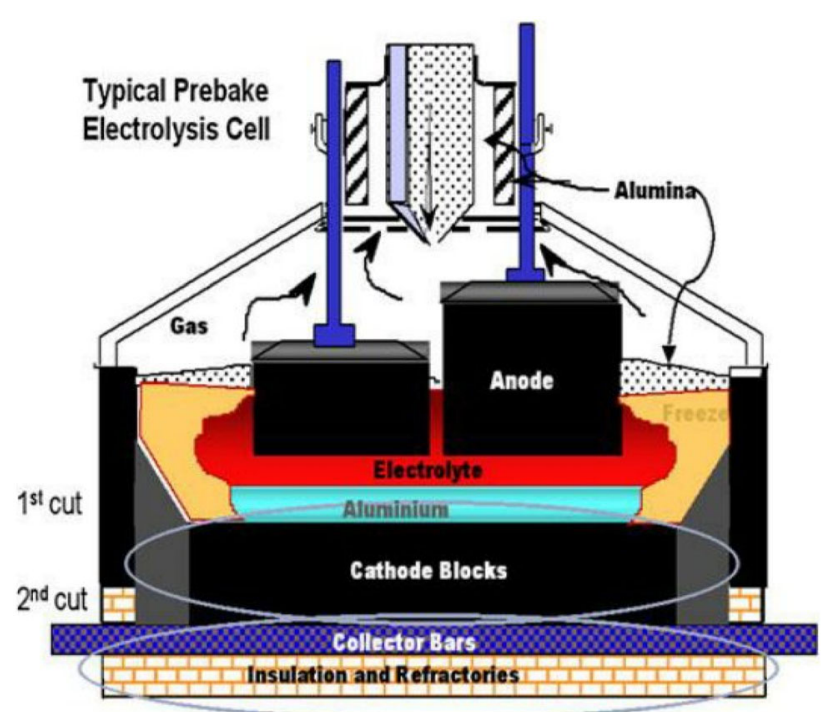

Fig. 1. Cross-section of a prebake aluminum cell (reprinted with permission from Ref. 8).

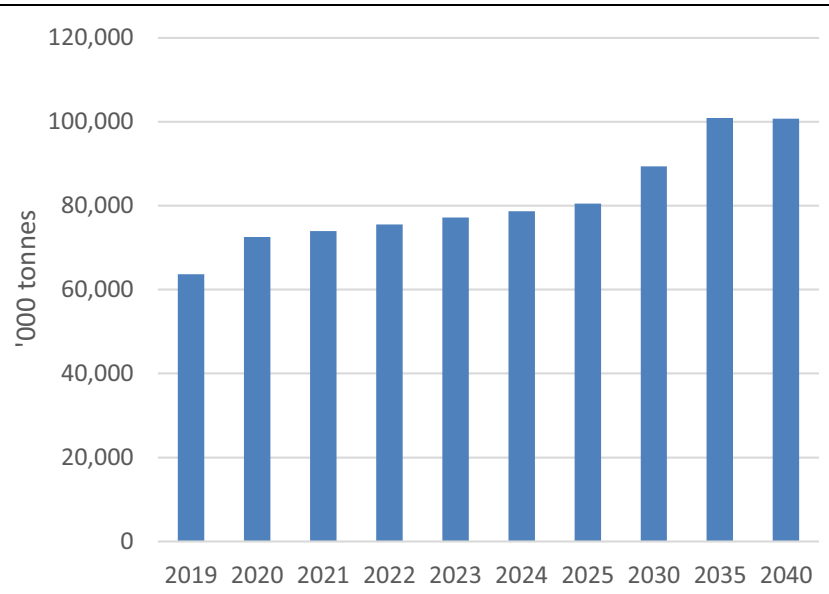

Fig. 2. Estimate of primary aluminum production to 2040 (data from Ref. 9).

significantly to 2040, and even with recycling opportunities maximized, an increase in primary aluminum production will be needed to meet demand (Fig. 2) ${ }^{9}$. This increase in primary aluminum production will also lead to increased SPL generation, and although there has been significant research on increasing the life of aluminum cells $^{10-12}$, completely removing SPL from the process is not yet possible, meaning that the challenge of managing SPL will continue to grow in the future ${ }^{3}$.

A comprehensive literature review was conducted as part of the IAI's work program. Information was collated from a range of sources including academic journals, conference proceedings, company presentations, sustainability reports, media reports, and regular discussion with industry. IAI members also provided supporting information about their current activities, future SPL management plans, and the regulatory landscape in various jurisdictions.

A recurrent theme that emerged from the literature review was reference to the waste management hierarchy as a guiding framework for plans and activities. This was also evident in many of the aluminum company SPL plans and disclosures ${ }^{13-15}$. The waste management hierarchy aims to firstly maximize the efficiency of process operations in order to minimize the generation of waste ${ }^{16}$. It then promotes the concepts and preference (in descending order of preference) towards reuse, recycling, recovery, and, where necessary, responsible disposal. Several studies and company sustainability reports ${ }^{3,17-19}$ explore the alignment of current SPL management options with the various levels of the waste management hierarchy (Fig. 3).

There is a wealth of literature on the various treatment options for SPL ${ }^{2,19,20}$. Many of the solutions are focused on removing the hazardous compounds from SPL through reaction with various reagents or through thermal destruction to produce useful by-products for use in other industries, or for disposal or storage ${ }^{2,13,17}$. Finding new ways to treat and manage SPL continues to be an active research area, but currently there are a limited number of commercial solutions available at scale. This means that estimates for the cost of treating SPL are relatively high at approximately US $\$ 1000 / \mathrm{t}^{21}$. The cost for landfilling across jurisdictions can also be highly variable and can be a major influence on the management approaches for SPL ${ }^{8}$.

Globally, SPL treatment takes place in a mix of company-owned (or established) treatment facilities (e.g., Rio Tinto's UTB, Gum Springs, Chalco Pingguo) or via third-party SPL processors (e.g., Regain Materials, Befesa, ROCKWOOL, Weston Aluminium). Some company-owned facilities have the capacity to process SPL from other operations, and this regularly happens within regions or where smelters are located in close proximity. Although today there are a range of commercial solutions available, it is estimated that more than $50 \%$ of SPL is still stockpiled or landfilled ${ }^{21}$.

In recent years, many aluminum companies have explored the use of SPL as a feedstock material or energy source in other processes, such as cement or steel production ${ }^{2,14}$. These industrial partnerships have typically been built on strong local relationships where companies can benefit from the close proximity of other industrial processes looking for alternative raw materials, and alignment on broader regional or national circular economy and resource efficiency objectives ${ }^{14,22}$. 


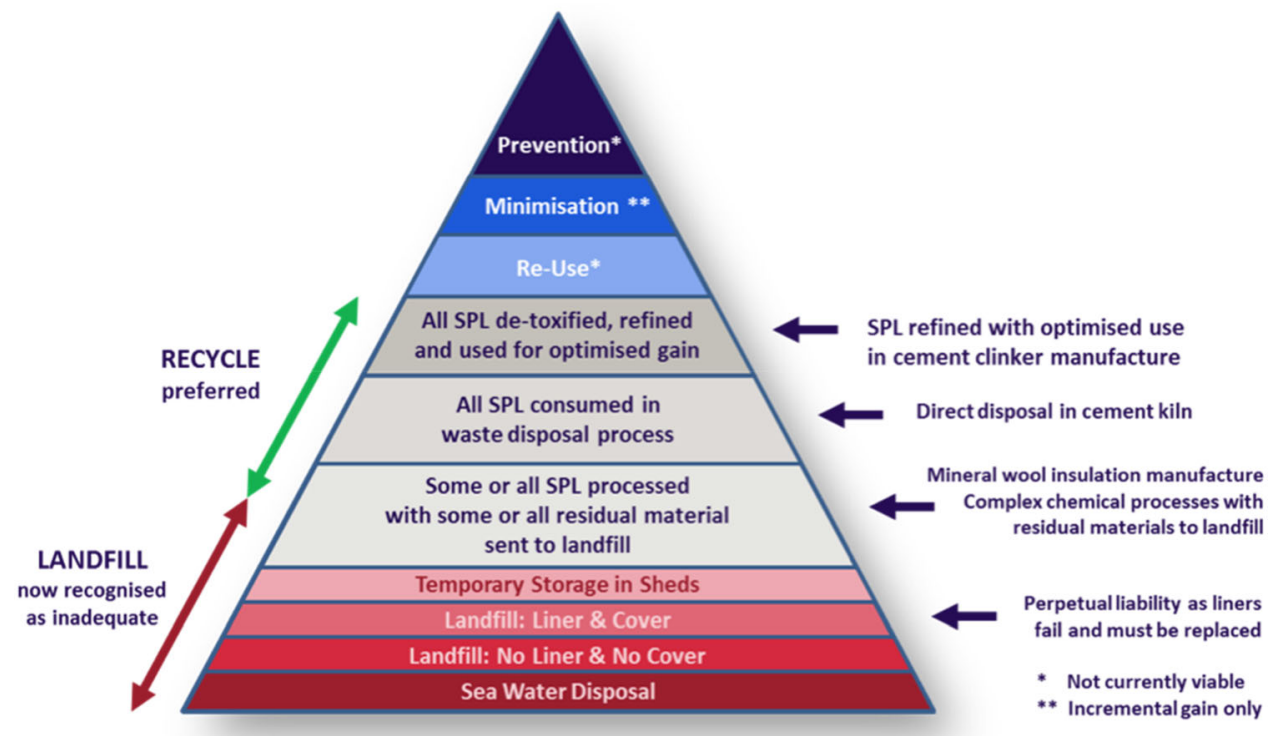

Fig. 3. SPL management practices and the waste management hierarchy (reprinted with permission from Ref. 3).

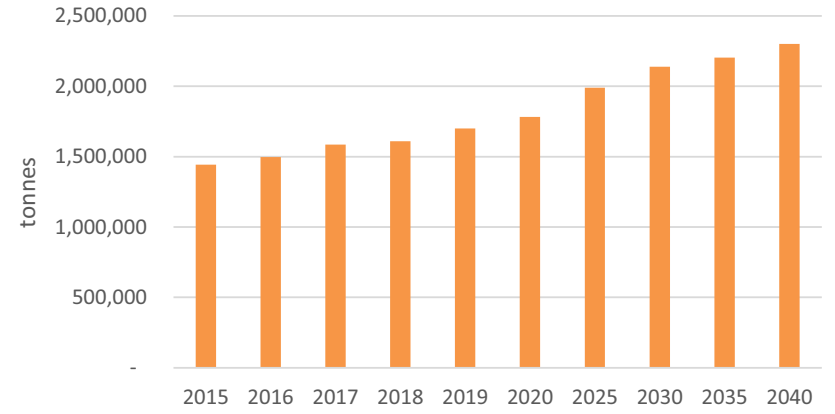

Fig. 4. Estimates of annual SPL generation (data from Refs.5 and 9).

\section{UNDERSTANDING THE CONTEXT: GLOBAL SPL GENERATION AND ACTIVITIES}

Using the data collected by the IAI as part of its regular industry surveys together with projections for the production of primary aluminum out to 2040, an estimate of current and future SPL generation per annum was made (Fig. 4). In 2019, approximately 1.6 million tonnes of SPL was generated from primary aluminum production. By 2040, SPL generation is expected to increase, in line with primary aluminum production growth, to $2.3 \mathrm{mil}-$ lion tonnes. Broek and Øye $(2020)^{19}$ analyzed the tonnages of SPL being treated or utilized in other processes outside of China and estimate that this is currently 300,000 tonnes. This represents approximately $40-50 \%$ of the SPL generated outside of China annually. Large-scale SPL treatment or management solutions in China are still relatively limited ${ }^{2,19,23}$.
An overview of global SPL activities was compiled as part of the guidance to demonstrate the breadth of management approaches (Fig. 5). It also identified regional clusters of activity and alignment in smelter approaches, often based on local factors. In the Middle East, for example, there is a prominent construction industry which means that industrial SPL users such as steel producers and cement producers are located nearby, which enables companies to build strategic partnerships and explore the potential to recycle SPL from aluminum smelters in other processes.

\section{ENGAGEMENT AND COLLABORATION: INDUSTRY WORKSHOPS AND GUIDANCE DEVELOPMENT}

To bring together different stakeholders, two SPL workshops were coordinated by the IAI to discuss issues and challenges related to SPL management. The first workshop took place in London in August 2018, and the second workshop was held in San Antonio in March 2019. A broad mix of stakeholders attended the workshops, with aluminum producers, industry associations, representatives from academia, and SPL treatment providers or processors represented at both workshops. Over 20 different stakeholders were involved across the two workshops and engaged in the discussions.

The workshop discussions included a review of the current landscape, ongoing activities, as well as a higher-level view on the global scale of the issue. The participants also explored the main challenges facing stakeholders, including those around regulatory barriers, stakeholder perception, and the longterm viability of some processing options. The 


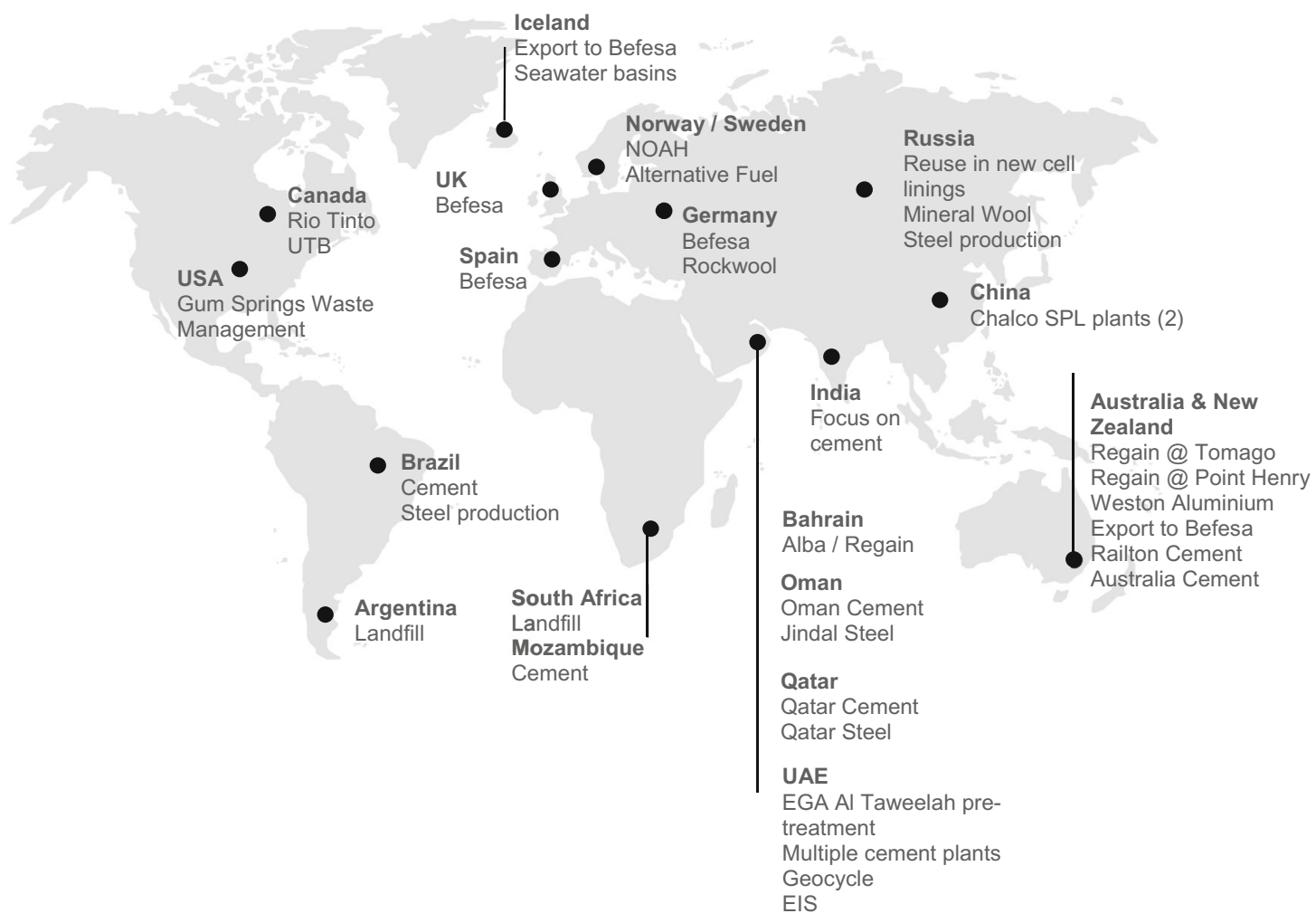

Fig. 5. General overview of current global SPL activities (2019) (reprinted with permission from Ref. 22).

workshop discussions culminated in a review of what could be done by the IAI to assist in improving the management of SPL across the industry.

A key outcome from the stakeholder workshops was the conclusion that industry guidance was needed and that the IAI had a role to play in bringing together a range of stakeholder views, published literature, and information on current activities, as it had done for other issues of concern $^{6,7}$. The discussions highlighted that there was an abundance of information and activity globally, but there was a need for a practical, comprehensive resource to bring together information and support stakeholders in their understanding or decisionmaking processes. An IAI SPL working group of experts was also formed to provide input and expertise during the guidance development process.

The SPL working group decided that the guidance should follow the framework set by previous IAI industry guidance ${ }^{6,7}$. The main aim of the SPL management guidance was to "identify the key elements of an effective SPL management plan and provide information and case studies to inform management plans and practices"22.

The guidance framework outlines background theory on specific issues, along with practical considerations, "do's and don'ts," followed by ways in which key risks could be mitigated and managed. The guidelines were written primarily for use by those managing or involved with SPL activities, including smelter managers, logistics providers, SPL processors, and SPL consuming industries, but other stakeholders including representatives of nongovernment organizations (NGOs), local communities, and government regulators may also find them useful.

For each key issue identified by the working group, an effort was made to find and develop suitable case studies to provide practical examples. The case studies were selected and developed to reflect a broad range of experiences across different jurisdictions. Case studies offer users real-life examples of the theory in practice and have proved valuable resources in previous guidance. The case studies included in the SPL guidance cover experiences across all major aluminum-producing regions and at all stages of the waste management hierarchy. A total of 13 case studies are included in the guidance, covering operations in Australia, Canada, India, Norway, Oman, Russia, the United Arab Emirates, and the USA. They include examples not only of the various solutions being implemented at sites but also strategic partnerships and the evolution of company SPL plans. The guidance is intended to be a useful resource for any stakeholder striving to improve the sustainability of their practices and not only those seeking best practice. The 
guidance and supporting case studies were developed during an iterative process involving various stakeholders over a period of 10 months.

One of the key outcomes of the guidance was that sustainable SPL management is not a single "one size fits all" prescription, and as such, the guidance is intended to be relatively flexible in its approach. There is a focus throughout on practical guidelines, the application of decision-making tools, and implementing systems using risked-based approaches rather than prescriptive solutions. Many of the issues related to SPL management will be influenced by local climatic, geographic, and environmental conditions as well as government policies, the regulatory framework, and societal or community factors, and these need evaluation on a case-bycase basis. Indeed, many companies choose to adopt a range of different strategies depending on the constantly changing site-specific situations.

\section{KEY ISSUES TO CONSIDER FOR SUSTAINABLE SPL MANAGEMENT}

Sustainable waste management should focus on protecting human health and the environment ${ }^{16}$ through appropriate planning, governance, storage, handling, treatment, transportation, and disposal processes. The guidance focuses on eight key issues to consider when developing a sustainable SPL management plan (Fig. 6). These areas are well aligned with other industry guidance related to sustainable practices including IAI guidance on sustainable bauxite mining ${ }^{7}$ and bauxite residue management ${ }^{6}$. The key issues that should be considered as part of an effective plan are summarized in Fig. 6 and the following section.

i. Long-Term Planning

SPL will be generated for the entirety of a smelter's life, and provision for waste management should be an integral part of the smelter's risk assessment and management process. SPL management plans should consider the waste management hierarchy, and solutions should be evaluated using a structured and systematic process to assess their suitability for each site and situation. Regular risk assessments should be carried out to review the environmental, social, economic, health, and safety risks associated with each SPL activity, and systems should be in place to manage, monitor, and mitigate these risks.

ii. Good Governance

Transparency is essential for good governance. The disclosure of information and good communication is important, as it can have a significant impact on the way in which SPL activities are managed. There should also be clear accountability of SPLrelated activities at all levels, from senior management through to operators and contractors. A good governance framework should, as a minimum, ensure that companies comply with all government regulations and laws applicable to their activities.

\section{SUSTAINABLE SPENT POT LINING MANAGEMENT :} KEY FEATURES \& CONSIDERATIONS

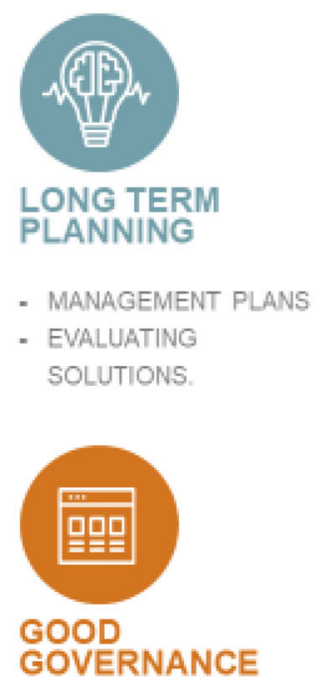

- KEY FACTORS

- REGULATORY COMPLIANCE
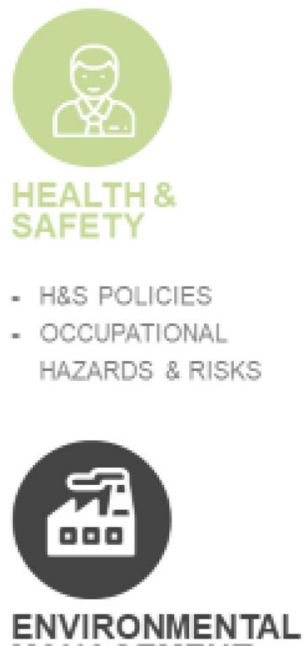
MANAGEMENT

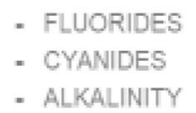

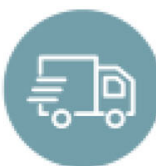

HANDLING, STORAGE \& TRANSPORT

- ON-SITE STORAGE DESIGN

- BASEL CONVENTION

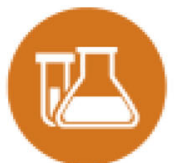

TREATMENT OPTIONS

- PRE-TREATMENT

- commercial OPTIONS
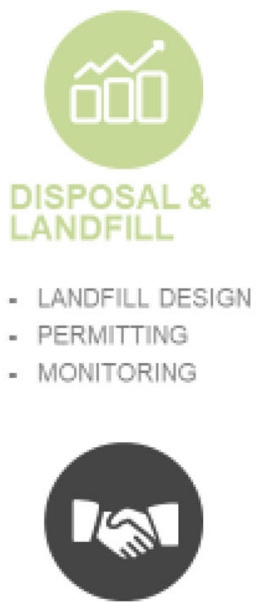

UTILISATION IN INDSUTRY

$$
\begin{aligned}
& \text { - CEMENT } \\
& \text { - STEEL } \\
& \text { - MINERAL WOOL }
\end{aligned}
$$

Fig. 6. Key areas identified for IAI sustainable SPL management guidance. 
iii. Health and Safety

A risk-based approach should be used to understand and manage health and safety impacts from the generation, handling, storage, transportation, treatment, and disposal of SPL. Companies have a responsibility to ensure the health and safety of all workers and local communities. This can be done by ensuring that workers are adequately qualified to undertake SPL activities and equipped with relevant equipment, manuals, and protocols and by providing regular health and safety training. A multi-stakeholder approach should be taken to develop, and implement, an emergency action plan to keep people and the environment safe.

v. Handling, Storage, and Transport

Regular risk assessments should be conducted at each stage to identify potential environmental, social, economic, health, and safety risks, and systems should be put in place to monitor and mitigate these risks. Regular training and documented protocols available for all workers could minimize the risks associated with SPL handling, storage, and transport. SPL's classification as a hazardous waste means that it is subject to strict rules for transportation including The Basel Convention on the Control of Transboundary Movements of Hazardous Wastes and their Disposal. Companies should ensure that they comply with all such regulation for safe handling, storage, and transport.

vi. Treatment Options

There is no single solution that could treat the global generation of SPL annually. There are many SPL treatment and processing solutions available, and these should be evaluated on a case-by-case basis to understand the best suited solution. Sitespecific issues (e.g., SPL characteristics, site location, regulatory influences, and local industry opportunities) should always be taken into consideration, as one size does not fit all.

vii. Disposal and Landfill

Landfill is the least preferred management option based on the waste management hierarchy. In some cases, reuse or treatment is not always possible, and if landfill is adopted as the last resort, then it must be done responsibly. Regular risk assessments should be conducted to identify all potential environmental, social, economic, health, and safety risks associated with disposal or landfilling, and systems should be put in place to monitor and mitigate these risks. Responsible parties should consult with relevant stakeholders including site owners, regulatory authorities, and local communi- ties to minimize impacts on the environment and human health. It is good practice to regularly review alternative approaches for SPL management.

viii. Utilization in Industry

Opportunities to collaborate with other industries to utilize SPL in industrial applications (e.g., cement, steel, and mineral wool) should be maximized where possible. In doing so, companies may be able to reduce their overall waste footprint and contribute to broader circular economy objectives. Utilization of SPL in other industries requires consideration of site-specific issues, e.g., SPL characteristics, site location, regulatory regime, and local industry opportunities.

\section{CONCLUSION: NOT ONE SIZE FITS ALL}

The aluminum industry, like many other industries, is cognizant that it must strive to achieve acceptably low social and environmental impacts from its processes. Effective and sustainable management of SPL has been a major challenge for the industry for many years, and although there are a number of commercial treatment solutions and industrial applications that can be part of the management solution for companies, there is potential to further improve the global industry's management of SPL.

An estimated 1.6 million tonnes of SPL is generated annually from the primary aluminum production process, and this is expected to increase over the next 20 years to 2.3 million tonnes. As the industry continues to find ways to manage growing tonnages of SPL with growing stakeholder expectations, the IAI has published industry guidance-developed through industry collaboration and sharing of expertise and good practice-focused on eight key areas: long-term planning, good governance, health and safety, environmental management, handling storage, and transport, treatment options, disposal and landfilling, and utilization of SPL in other industries.

Sustainable SPL management is not a single onesize-fits-all prescription, and the new guidance published by the IAI is intended to inform stakeholders on the current landscape, key risks, and management strategies available across a range of different circumstances. It is intended that this guidance be relevant to all current aluminum smelters producing SPL and striving to manage waste sustainably, not just those who are seeking to achieve best practice. The guidance is a first step towards improving practices and informing industry waste management plans. There is now an opportunity for further discussion, collaboration, and broader engagement to maximize the impact of this work and further reduce the environmental impact of primary aluminum production processes. 


\section{OPEN ACCESS}

This article is licensed under a Creative Commons Attribution 4.0 International License, which permits use, sharing, adaptation, distribution and reproduction in any medium or format, as long as you give appropriate credit to the original author(s) and the source, provide a link to the Creative Commons licence, and indicate if changes were made. The images or other third party material in this article are included in the article's Creative Commons licence, unless indicated otherwise in a credit line to the material. If material is not included in the article's Creative Commons licence and your intended use is not permitted by statutory regulation or exceeds the permitted use, you will need to obtain permission directly from the copyright holder. To view a copy of this licence, visit http://creativecommons.org/licenses/by/4.0/.

\section{REFERENCES}

1. Regain Materials, Spent Potliner Challenges (Regain Materials, 2018), http://www.regainmaterials.com/alumi nium-smelting-industry/spent-potlining-challenges. Accessed 18 February 2020.

2. S. Broek and H. A. Øye, Fundamentals of managing spent potlining (SPL), in Proceedings of the 36th International ICSOBA Conference, Belem, Brazil, 2018https://icsoba.org/a ssets/files/list-of-papers-2018/aluminium-papers-2018/A L21\%20-\%20Fundamentals\%20of\%20Managing\%20Spent $\%$ 20Potlining\%20(SPL).pdf. Accessed 18 February 2020.

3. P. Black, The legacy of spent potliner - cost or opportunity? (Light Metal Age, 2016),https://www.lightmetalage.com/ne ws/blog/the-legacy-of-spent-potliner-cost-or-opportunity/. Accessed 19 February 2020.

4. P. Randell, and G. Latimer, Spent pot lining project (feasibility of an agreement-based approach to clear stockpiles) (Randell Environmental Consulting, 2016). https://www.en vironment.gov.au/system/files/resources/d5397e69-4af3-48e d-afcd-1d2a687bd33e/files/spent-pot-lining-project.pdf. Accessed 19 February 2020.

5. International Aluminium Institute, 2015 Life Cycle Inventory and Environmental Metrics Report for the Primary Aluminium Industry (IAI, 2017). http://www.world-alumi nium.org/media/filer_public/2017/07/04/appendix_a_-_life_c ycle_inventory.xlsx. Accessed 19 February 2020.

6. International Aluminium Institute, Bauxite Residue Management: Best Practice (IAI, 2015) Available from: http:// www.world-aluminium.org/media/filer_public/2015/10/15/ba uxite_residue_management_-_best_practice_english_oct15e dit.pdf. Accessed 19 February 2020.

7. International Aluminium Institute, Sustainable Bauxite Mining Guidelines (IAI, 2018), http://www.world-alumi nium.org/media/filer_public/2018/05/18/170518_sbmg_final. pdf. Accessed 19 February 2020.

8. S. Parhi, Gainful utilization of spent pot lining-A Hazardous Waste from aluminum industry (National Institute of Technology, Rourkela Department of Chemical Engineering 2014), https://core.ac.uk/download/pdf/80147471.pdf . Accessed 19 February 2020.

9. International Aluminium Institute. Global Mass Flow Model (IAI, 2018), http://www.world-aluminium.org/publications/t agged/mass $\% 20$ flow/.

10. W.R. Hale, JOM (1989). https://doi.org/10.1007/B F03220379.

11. B. Welch, JOM (1999). https://doi.org/10.1007/s11837-9990036-4.

12. P. Lavoie, Adv. Mater. Res. (2011). https://doi.org/10.4028/ www.scientific.net/amr.275.93.

13. L. Birry, S. Leclerc, and S. Poirier, Light Metals (2016). h ttps://doi.org/10.1002/9781119274780.ch77.

14. Emirates Global Aluminium, Sustainability Report 2017 (EGA, 2017), https://www.ega.ae/media/1538/ega-2017-sus tainability-report.pdf. Accessed 28 February 2020.

15. UC Rusal, Sustainability Report 2017, (UC RUSAL, 2017), h ttps://rusal.ru/upload/iblock/b93/LTN201807271059.pdf. Accessed 28 February 2020.

16. United Nations (UN). Waste Management (UN, 2011), htt ps://sustainabledevelopment.un.org/content/documents/dsd/ dsd_aofw_ni/ni_pdfs/NationalReports/sweden/WasteManag ement.pdf. Accessed 28 February 2020.

17. P. Black and B. Cooper. An Industrial Ecology SPL solution (Aluminium International Today, 2015), https://issuu.com/ quartzmetals/docs/aluminium_international_today_. Accessed 28 February 2020.

18. Hindalco. Sustainability Report (Hindalco, 2018), http://w ww.hindalco.com/upload/pdf/sustainability-report-2018-19. pdf. Accessed 28 February 2020.

19. S. Broek and H. A Øye. Formation, Characterization and Treatment of Spent Potlining Short Course (TMS Annual Meeting, 2020).

20. M. Sørli and H.A. Øye, Cathodes in Aluminium Electrolysis, 3rd ed. (Düsseldorf: Aluminium Verlag Marketing und Kommunikation, 2010), p. 662.

21. H. A. Øye. Discussion of industrial spent pot lining treatment, in Proceedings of 35th International ICSOBA Conference, Hamburg, Germany, 2017), https://pdfs.semantic scholar.org/4d65/0b2fb2f27bf996a55ad1227a8c135fa8755d.p df. Accessed 4 March 2020.

22. International Aluminium Institute. Sustainable Spent Pot Lining Guidance (IAI, 2020), http://www.world-aluminium. org/media/filer_public/2020/03/16/final_spl_guidance_-16_m ar_2020.pdf. Accessed 12 March 2020.

23. W. Li and X. Chen, Essent. Read. Light Metals (2016). https://doi.org/10.1007/978-3-319-48200-2_143.

Publisher's Note Springer Nature remains neutral with regard to jurisdictional claims in published maps and institutional affiliations. 